2. Rosenhek R, Rader F, Klaar U, Gabriel H, Krejc M, Kalbeck D, et al. Outcome of watchful waiting in asymptomatic severe mitral regurgitation. Circulation. 2006; 113:2238-44.

3. Avierinos JF, Gersh BJ, Melton LJ. Natural history of asymptomatic mitral valve prolapse in the community. ACC Curr J Rev. 2003;12: $37-8$.

4. Nishimura RA, Otto CM, Bonow RO, Carabello BA, Erwin JP III, Fleisher LA, et al. 2017 AHA/ACC focused update of the 2014 AHA/ACC guideline for the management of patients with valvular heart disease. J Am Coll Cardiol. 2017; 70:252-89.

5. Corporan D, Onohara D, Amendi A, Saadeh M, Guton RA, Kumar S, et al. Hemodynamic and transcriptomic studies suggest early left ventricular dysfunction in a preclinical model of severe mitral regurgitation. J Thorac Cardiovasc Surg. 2021; 161:961-76.e22.

6. Lelovas PP, Kostomitsopoulos NG, Xanthos TT. A comparative anatomic and physiologic overview of the porcine heart. J Am Assoc Lab Anim Sci. 2014;53:432-8.
See Article page 961.

\section{Commentary: Can indications for asymptomatic mitral regurgitation derive from ratatouille or should we stew on it?}

Edward Buratto, MBBS, $\mathrm{PhD},{ }^{\mathrm{a}, \mathrm{b}, \mathrm{c}}$ and Igor E. Konstantinov, MD, PhD, FRACS ${ }^{\mathrm{a}, \mathrm{b}, \mathrm{c}, \mathrm{d}}$

Chronic mitral regurgitation (MR) is associated with progressive left ventricular (LV) volume loading, yet these patients may remain asymptomatic for many years without displaying any decrease in LV ejection fraction. ${ }^{1}$ It has been postulated that chronic severe MR may be associated with ventricular dysfunction that is not manifested as reduced ejection fraction. ${ }^{1,2}$ Furthermore, it has been observed that patients with preserved LV function who undergo mitral repair frequently have postoperative $\mathrm{LV}$ dysfunction. ${ }^{1}$ An interesting article by Corporan and colleagues ${ }^{3}$ describes an experimental rat model of MR, achieved by surgically perforating the anterior mitral leaflet. Over a period of 40 weeks, they observed that ventricular dilatation,

From the a Department of Cardiac Surgery, Royal Children's Hospital, Melbourne, Australia; 'bepartment of Paediatrics, University of Melbourne, Melbourne, Australia; 'Heart Research Group, Murdoch Children's Research Institute, Melbourne, Australia; and ${ }^{\mathrm{d}}$ Melbourne Centre for Cardiovascular Genomics and Regenerative Medicine, Melbourne, Australia.

Disclosures: The authors reported no conflicts of interest.

The Journal policy requires editors and reviewers to disclose conflicts of interest and to decline handling or reviewing manuscripts for which they may have a conflict of interest. The editors and reviewers of this article have no conflicts of interest.

Received for publication Aug 31, 2020; revisions received Aug 31, 2020; accepted for publication Sept 1, 2020; available ahead of print Sept 4, 2020.

Address for reprints: Igor E. Konstantinov, MD, PhD, FRACS, Department of Cardiac Surgery, Royal Children's Hospital, Flemington Rd, Parkville, 3029, Australia (E-mail: igor.konstantinov@rch.org.au).

J Thorac Cardiovasc Surg 2021;161:978-9

0022-5223/ $\$ 36.00$

Crown Copyright $(2020$ Published by Elsevier Inc. on behalf of The American Association for Thoracic Surgery

https://doi.org/10.1016/j.jtcvs.2020.09.006
Check for updates

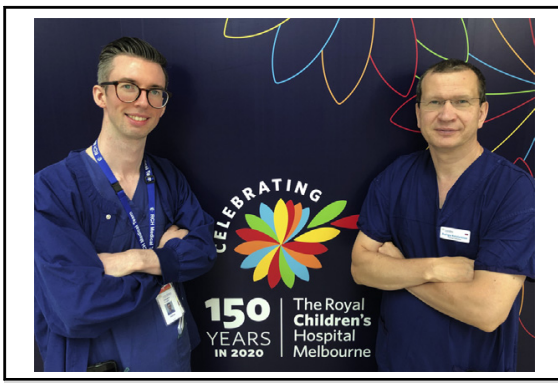

Edward Buratto, MBBS, PhD, and Igor E. Konstantinov, MD, PhD, FRACS

CENTRAL MESSAGE

In rat models of mitral regurgi-

tation, myocardial remodeling

may precede a fall in ejection

fraction.

impaired LV contractility, transcriptomic changes, myocardial remodeling, and oxidative stress pathways activation preceded a fall in LV ejection fraction. This appeared to be biological evidence to support the concept that ventricular dysfunction and adverse remodeling predates the fall in ejection fraction in patients with severe MR. Yet, this diverse mixture of transcriptomic changes, myocardial remodeling, and ventricular dilatation observed in rats is much like a thick ratatouille, the pieces of which are very difficult to separate and even harder to make sense of. Based on the findings in the rat model, it is difficult to make any clinical inferences for surgical management of asymptomatic patients with severe mitral insufficiency.

Given the concern of potential LV dysfunction despite preserved ejection fraction, the most recent American Heart Association guidelines recommend mitral repair in asymptomatic individuals with preserved ejection fraction if the probability of repair is $>95 \%$ and the risk of mortality $<1 \%$. Are we able to achieve these lofty ambitions? It is a fascinating fact that a recent report on 2259 patients from New York State hospitals who underwent mitral 
surgery for severe asymptomatic MR with preserved ejection fraction demonstrated that only $63 \%$ of patients received a mitral repair. ${ }^{5}$ Even amongst surgeons with the highest volume (ie, $>47$ mitral surgeries per year) the repair rate only reached $92 \% .^{5}$ Furthermore, in a propensity matched analysis, patients who underwent mitral replacement had a significantly higher mortality at 4 years $(12.1 \%$ vs $3.5 \% ; P<.001)$. A mortality rate of $12 \%$ at 4 years in patients without heart failure and with preserved LV function is startling. ${ }^{5}$ Even in the most experienced hands, a repair rate of $>95 \%$ appears to be difficult to achieve. Although excellent results with complex mitral valve repair have been reported, ${ }^{6}$ it would still be not easy to recommend mitral valve repair in all asymptomatic patients with severe mitral insufficiency. Or would it?

The current, thought-provoking study by Corporan and colleagues ${ }^{2}$ is timely and very important because it suggests that, at least in rats, irreversible myocardial remodeling may occur before a significant fall in ventricular ejection fraction. This appears to be a highly valuable observation for all of us to consider.

\section{References}

1. Quintana E, Suri RM, Thalji NM, Daly RC, Dearani JA, Burkhart HM, et al. Left ventricular dysfunction after mitral valve repair-the fallacy of "normal" preoperative myocardial function. J Thorac Cardiovasc Surg. 2014;148:2752-60.

2. Yuh DD. Commentary: Mitral repair in symptom-free patients with normal ventricles: becoming the new normal? J Thorac Cardiovasc Surg. 2019;157:1440-1.

3. Corporan D, Onohara D, Amedi A, Saadeh M, Guyton RA, Kumar S, et al. Hemodynamic and transcriptomic studies suggest early left ventricular dysfunction in a preclinical model of severe mitral regurgitation. J Thorac Cardiovasc Surg. 2021; 161:961-76.e22.

4. Nishimura RA, Otto CM, Bonow RO, Carabello BA, Erwin JP III, Fleisher LA, et al. 2017 AHA/ACC focused update of the 2014 AHA/ACC guideline for the management of patients with valvular heart disease: a report of the American College of Cardiology/American Heart Association task force on clinical practice guidelines. J Am Coll Cardiol. 2017;70:252-89.

5. Hannan EL, Samadashvili Z, Smith CR, Lahey SJ, Gold JP, Jordan D, et al. Mitral valve repair versus replacement for patients with preserved left ventricular function without heart failure symptoms. J Thorac Cardiovasc Surg. 2019;157: 1432-9.

6. David TE, David CM, Lafreniere-Roula M, Manlhiot C. Long-term outcomes of chordal replacement with expanded polytetrafluoroethylene sutures to repair mitral leaflet prolapse. J Thorac Cardiovasc Surg. 2020;160:385-94.

\section{Commentary: The mitral matrix}

\section{Tomasz A. Timek, MD, PhD}

Well-standardized mitral repair techniques have provided predictable and durable results for patients with degenerative mitral regurgitation, ${ }^{1}$ yet the timing of surgical intervention in asymptomatic patients continues to be debated. Current guidelines ${ }^{2}$ focus on left ventricular size and ejection fraction whereas some investigators suggest the use of more subtle markers such as left atrial volume index, ${ }^{3}$ myocardial strain, ${ }^{4}$ and circulating peptides ${ }^{5}$ in asymptomatic patients. Although watchful waiting with close surveillance has shown to be safe, fears arise that myocardial

\footnotetext{
From the Division of Cardiothoracic Surgery, Spectrum Health; and Michigan State University College of Human Medicine, Grand Rapids, Mich.

Disclosures: The author reported no conflicts of interest.

The Journal policy requires editors and reviewers to disclose conflicts of interest and to decline handling or reviewing manuscripts for which they may have a conflict of interest. The editors and reviewers of this article have no conflicts of interest.

Received for publication Sept 20, 2020; revisions received Sept 20, 2020; accepted for publication Sept 23, 2020; available ahead of print Sept 28, 2020.

Address for reprints: Tomasz A. Timek, MD, PhD, Division of Cardiothoracic Surgery, Spectrum Health, 100 Michigan Ave NE, Grand Rapids, MI 49503 (E-mail: tomasz.timek@spectrumhealth.org).

J Thorac Cardiovasc Surg 2021;161:979-80

0022-5223/\$36.00

Copyright (c) 2020 by The American Association for Thoracic Surgery

https://doi.org/10.1016/j.jtcvs.2020.09.087
}

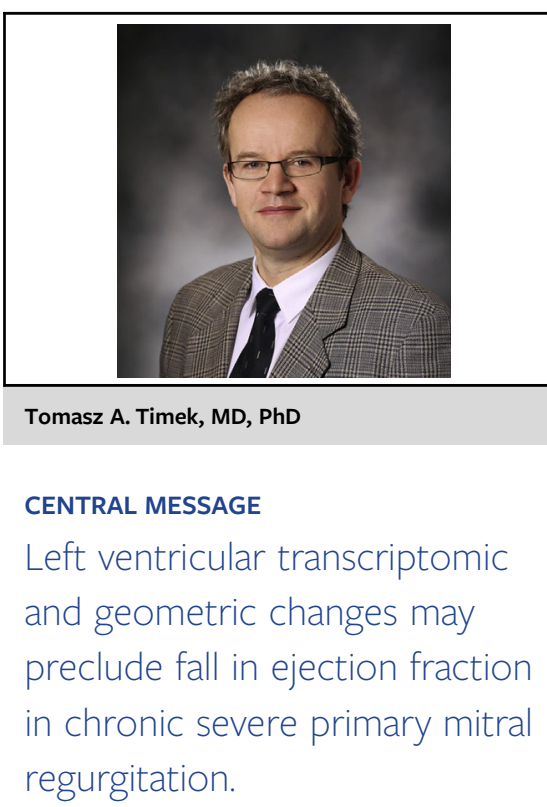

damage may be occurring even in the setting of preserved ventricular function.

Based on the experimental data presented by Corporan and colleagues ${ }^{6}$ in this issue of the Journal, these fears may not be unfounded. The investigators from Emory 